\title{
Assessing vulnerability of subsistence travel to effects of environmental change in Interior Alaska
}

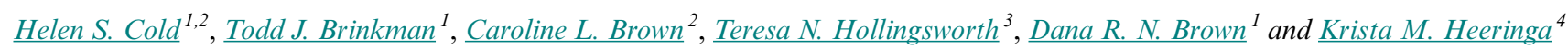

\begin{abstract}
Amplified climate warming at high northern latitudes is challenging societies that depend on local provisional and cultural ecosystem services, e.g., subsistence resources, for their livelihoods. Previous qualitative research suggests that climate-induced changes in environmental conditions are affecting rural residents' ability to travel across the land and access local resources, but detailed information on the nature and effect of specific conditions is lacking. Our objectives were to identify climate-related environmental conditions affecting subsistence travel and access, and then estimate rural resident travel and access vulnerability to those environmental conditions. We collaborated with nine Interior Alaskan communities within the Yukon River basin and provided residents with cameraequipped GPS units to document environmental conditions directly affecting subsistence access for 12 consecutive months. We also conducted comprehensive interviews with research participants to incorporate the effects of environmental conditions not documented with GPS units. Environmental conditions reported by rural residents were categorized into seven condition types. We assessed vulnerability to each condition by accounting for both likelihood (number of times a condition was documented) and sensitivity (magnitude of the effect from the condition) information derived from GPS observations and interviews. We also tested for differences in mean vulnerability values among environmental conditions and between community types (road-connected vs. remote) using a oneway analysis of variance. Rural community travel and access were most vulnerable to changes in ice conditions, erosion, vegetative community composition, and water levels. Environmental conditions that impeded natural travel corridors, e.g., waterways, more strongly influenced remote communities than those connected by roads. Increased vulnerability to environmental change puts remote communities at increased risk for food-security issues. Our study used a novel community-based approach to integrate local knowledge with scientific analysis to document and estimate the relative effects that specific environmental conditions are having on access to subsistence resources across Interior Alaska.
\end{abstract}

Key Words: access; Arctic; climate warming; subsistence; traditional ecological knowledge; travel; vulnerability

\section{INTRODUCTION}

Accelerated climate warming affects how human societies interact with their natural environments (Ford and Pearce 2012, Brinkman et al. 2016). Since the late 1960s, amplified and unprecedented climate shifts in northern biomes have altered the structure and function of ecosystems, and this trend will likely continue throughout the remainder of the 21st century (Bieniek et al. 2014, IPCC 2014, USGCRP 2018). These rapid rates of change in ecosystems are altering human-environment interactions, creating the need for societies to adapt to new conditions (Ford and Pearce 2012). In northern regions, climate-related changes in the environment are resulting in significant consequences for many rural communities that depend on resources obtained from the natural environment (Berkes and Jolly 2001, Ford and Pearce 2012). These provisional and cultural resources on which households rely are often jointly referred to as subsistence resources (Huntington and Fox 2005, Ford and Furgal 2009). State (Alaska Statute 16.05.258) and federal (Alaska National Interest Lands Conservation Act [ANILCA]; Public Law 96-487, Title VIII) law defines subsistence as the customary and traditional use of fish and wildlife for food, shelter, fuel, clothing, tools, transportation, handicraft articles, customary trade, barter, and sharing.

Over the last 30 years, subsistence harvests in the Arctic-Boreal region of Alaska have declined by 30-50\% (Wolfe and Walker 1987, Fall 2018). Although harvest declines are due to a variety of interconnected social, economic, regulatory, and environmental factors, subsistence harvesters have increasingly expressed concerns regarding challenges to their ability to traverse the landscape to reach subsistence use areas. Travel-related challenges and concerns include safety considerations (Brubaker et al. 2011, Schneider et al. 2013, Clark et al. 2016, Driscoll et al. 2016), amount of time necessary to access specific resources (Holen et al. 2012), monetary costs of accessing and harvesting resources (Brinkman et al. 2014), changes in the quantity and distribution of resources (Berman and Kofinas 2004), and unpredictable conditions in the physical environment (Berkes and Jolly 2001, Porter et al. 2014, Brinkman et al. 2016). To date, the descriptions of relationships between changes in accessibility and environmental conditions have been mainly qualitative. Few studies contain spatially and temporally explicit details on specific environmental conditions affecting resource access, and few data exist on the frequency, causes, and implications of such changes. Also, the relative impacts of different environmental conditions on resource access have received minimal attention. For example, recent research illustrated the importance of considering how changes in seasonality, sea ice, snow, and forest conditions influence the accessibility of resources by subsistence hunters (Berman and Kofinas 2004, Brinkman et al. 2016). However, the extent and characteristics of conditions that are impacting access were not documented. J. S. Magdanz et al. (2016, unpublished manuscript, https://doi.org/10.2139/ssrn.2779464) suggested that rural community characteristics, such as connectedness to road networks, may influence subsistence resource harvests. This could

${ }^{1}$ Institute of Arctic Biology, University of Alaska Fairbanks, ${ }^{2}$ Alaska Department of Fish and Game, ${ }^{3}$ USDA Forest Service, PNW Research Station, ${ }^{4}$ International Arctic Research Center, University of Alaska Fairbanks 
be due in part to increased competition from urban resource harvesters and a wider variety of travel options available to residents of road-connected communities.

Many of the social and ecological implications of environmental changes reported by rural Alaskans have been studied individually. Examples related to subsistence travel and access include insufficient snow accumulation (Hinzman et al. 2005, Moerlein and Carothers 2012, Carothers et al. 2014), thawing permafrost accelerating land slumping and riverbank erosion, (Hinzman et al. 2005, Moerlein and Carothers 2012, Brinkman et al. 2016), and climate-related shrub expansion and encroachment (Huntington and Fox 2005, McNeely et al. 2011, Brinkman et. al. 2016). However, a comprehensive understanding of the relative influence of multiple environmental conditions on travel and access to subsistence resources is lacking. In this study we used a community-based vulnerability assessment approach (IPCC 2001) to analyze complementary datasets derived from observations documented by rural harvesters in Alaska to identify key environmental changes affecting resource access.

Community-based participatory research (CBPR) methodology involves equitable partnerships among academic, community, agency, and nongovernment entities (Conrad and Hilchey 2011, Johnson et al. 2015). CBPR fosters inclusion of local ecological knowledge (LEK), which is knowledge and experience obtained through extensive observation of the natural world that is accumulated over several decades to many generations. LEK offers perspectives on connections between environmental trends and subsistence resources from individuals intimately connected to the land and natural processes (Huntington 2000, Huntington and Fox 2005, Pearce et al. 2015). We assessed how climate-related environmental conditions restrict or facilitate access to traditional and customary use areas. Our research objectives were to: (1) identify and classify conditions affecting access during a variety of subsistence activities, (2) quantify the vulnerability of travel and access to each class of condition, and (3) explore whether connectedness to the road system influences communities' vulnerability to conditions. Our findings can help direct the development of adaptive strategies specific to subsistence communities and enhance understanding on the societal relevance of future biophysical research on climate warming.

\section{METHODS}

\section{Study area}

Nine rural communities within the Yukon River basin of Interior Alaska participated in our study (Fig. 1). Our study area spans the central portion of Alaska from the Canadian border in the east to the Bering Sea in the west and covers approximately $832,700 \mathrm{~km}^{2}$. Mean temperatures range from $-29{ }^{\circ} \mathrm{C}$ in January to $17^{\circ} \mathrm{C}$ in July, and mean annual rainfall and snowfall are $50 \mathrm{~cm}$ and $160 \mathrm{~cm}$, respectively. Our study area incorporates six climatic zones, 20 ecoregions (Brabets et al. 2000), and a complex vegetation mosaic with many different vegetation types (Viereck et al. 1992), including all six Interior Alaska tree species (Picea glauca, P. mariana, Betula papyrifera, Populus balsamifera, $P$. tremuloides, Larix laricina), taiga shrublands, fens, and bogs. The Yukon River basin contains primarily discontinuous permafrost and experiences extensive and frequent wildfires. The study area contains communities both on $(n=6)$ and off $(n=3)$ the road network. Communities connected to roads have different socioeconomic demographics than communities off the road network, and the presence of roads can affect both level of dependence on subsistence resources and mode of transportation used to access harvest areas (J. S. Magdanz et al. 2016, unpublished manuscript). Residents of these communities harvest birds, fish, plants, and mammals for food, fiber, fuel, and medicinal purposes.

Fig. 1. Map of project study area depicting the nine collaborating communities across the Yukon River basin.

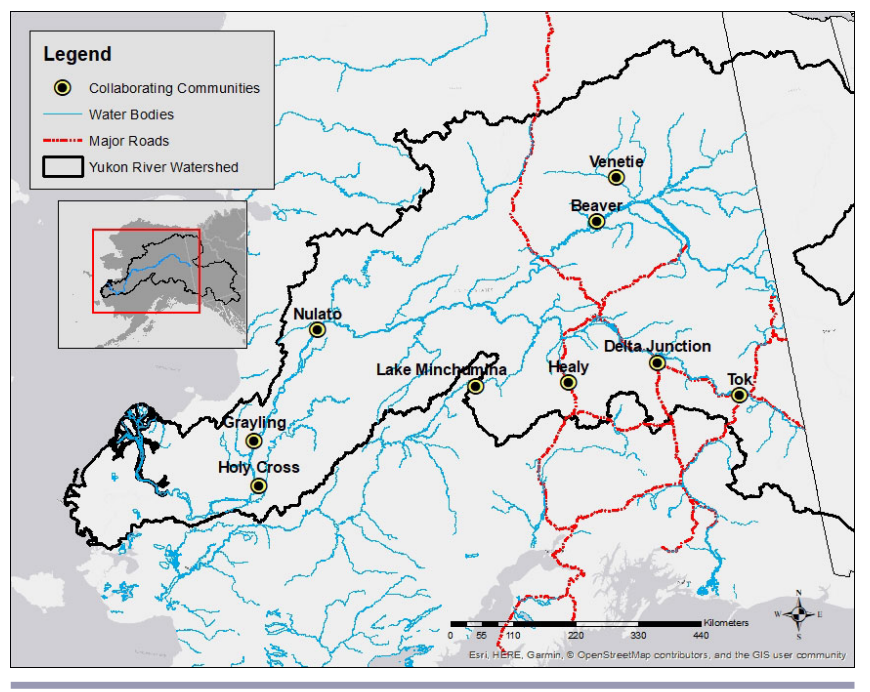

\section{Community engagement}

We invited individual communities to partner with us by way of community-wide informational meetings organized through local governing bodies (e.g., Tribal Council, Fish and Game Advisory Councils) within each community. Although we carefully sought involvement of communities that perceived a local benefit from engagement, we also synchronized recruitment efforts across the region to capture (1) a broad representation of differences in resource use and landscape characteristics across Interior Alaska, and (2) representation of communities both on and off the road system. We made initial contact with community organizations by phone or email to determine community interest in collaboration. If communities expressed interest, we scheduled on-site informational meetings to provide details on the goals, methods, and expectations of the project. We obtained formal written approval (e.g., Tribal Resolution) from a representative community entity (e.g., Tribal Council, Fish and Game Local Advisory Committee) prior to beginning research. Each representative entity selected two to three residents (hereafter "harvesters") within their community to participate as citizen scientists. Harvesters actively participated in subsistence and had in-depth experience and knowledge of traditional harvest areas around each community.

\section{Road-connected communities}

Three participating communities were located along major highways connected to urban areas: Tok (pop. 1239), Delta Junction (pop. 1050), and Healy (pop. 1115; U.S. Census Bureau 2016). Most residents are of primarily European descent, while the remainder mainly identify as Native Alaskan. Nearly all 
households in these communities report using subsistence resources, which consist primarily of large land mammals such as moose (Alces alces) and caribou (Rangifer tarandus) and both Pacific salmon (Oncorhynchus spp.) and nonsalmon fish (Holen et al. 2012). Subsistence harvests are facilitated by roads, trails suitable for motorized traffic, and navigable waterways. Modes of travel consist of passenger vehicles, boats, snowmobiles (known as "snowmachines" in Alaska), and ATVs. Access to commercial resources including fuel and food is facilitated by proximity to the road network, and costs for commercial goods are considerably less compared to more remote communities (Goldsmith 2007). These factors often work in conjunction to decrease the dependence of road-connected communities on subsistence resources (J. S. Magdanz et al. 2016, unpublished manuscript), although these resources remain important to the cultures, nutrition, and economies of road-connected communities.

\section{Remote communities}

Three communities in the western reaches of Interior Alaska participated in the study: Nulato (pop. 286), Grayling (pop. 165) and Holy Cross (pop. 216; U.S. Census Bureau 2016). Residents identify as primarily Koyukon, Holikachuk, and Deg Hit'an Athabascan, respectively, and are heavily reliant on subsistence resources. Salmon, including Chinook (O. tshawytscha) and chum (O. keta), as well as moose are important local food resources. Trapping of furbearing mammals including wolf (Canis lupus), marten (Martes americana), wolverine (Gulo gulo), lynx (Felis canadensis), beaver (Castor Canadensis), and muskrat (Ondatra zibethicus) provide both food and economic opportunity through fur sales for many residents (Ikuta et al. 2014, Brown et al. 2015).

Lake Minchumina (pop. 29) is located just outside the northwestern corner of Denali National Park, bordered to the southeast by the Alaska Range and to the west by the Kuskokwim mountains (U.S. Census Bureau 2016). Current residents are mostly of European ancestry, although the community was historically Koyukon Athabascan. Unlike the other communities, Lake Minchumina is not near a major river. The lake is the focal point for most activities, including transportation and acquisition of food and drinking water. Primary subsistence resources include nonsalmon fish species and moose (Holen et al. 2006) and many residents trap furbearers for income.

Venetie (pop. 171) and Beaver (pop. 46), are remote villages representing the northeastern region of the study area (U.S. Census Bureau 2016). These communities were historically very involved in fur trading with Russian settlers, and many residents still trap furbearing mammals for sale and personal use. Residents are primarily Gwich'in and Koyukon Athabascan, and a vast majority (> 90\%) actively harvest subsistence resources. Similar to remote study communities on the lower reaches of the Yukon, residents of Venetie and Beaver use resources primarily for consumption (moose, caribou, and salmon) (Holen et al. 2012).

All remote communities access harvest areas mainly by snowmachine, ATV, or boat. Travel and transportation of commercial goods and services for all remote study communities is restricted to light aircraft and limited boat service.

\section{Documentation of environmental conditions}

We developed a community-based monitoring program that provided local participants the opportunity to determine which conditions were important, rather than researchers. Each harvester received a camera-equipped GPS unit to collect photos and spatial coordinates of environmental conditions affecting travel and access. A purposefully open design reduced the possibility of bias in the documentation process. Photo dates and coordinates augmented with paper data recorded by harvesters insured accurate photo interpretation (Appendix 1). Harvesters described the photograph, subsistence activity being conducted, how access to resources was affected, how frequently the condition has been observed, when the condition was first observed, how the condition affected travel safety, and to what spatial extent they witnessed this condition. We used these data to parameterize components of an equation that assessed vulnerability of communities to different environmental conditions. Harvesters documented observations of environmental conditions affecting access for a 12-month period. As communities began participating on a rolling basis, harvesters collected data from March 2016 through July of 2017. In some cases harvesters preferred to capture spatially and temporally explicit images using personal smartphones in lieu of the provided GPS units, but information collected via either method was identical.

\section{Comprehensive interviews}

We conducted semistructured interviews (Huntington 2000, Carothers et al. 2014) to document environmental changes that may not have been obtained using GPS documentation. Some environmental conditions preclude all subsistence activities, resulting in a lack of documentation of highly relevant information. For example, a lack of snow during the first few weeks of the furbearer-trapping season could inhibit snowmachine travel to access trap lines. Therefore, there may be time periods when local residents are unable to get out on the land and document observations with GPS units.

Researchers interviewed project participants in every collaborating community except Healy because those individuals were unavailable for interviews during this part of the study. We also followed the suggestion of community leaders in Nulato, Grayling, and Venetie to interview several individuals that had not collected GPS data but were considered representative sources for LEK. Interview questions followed a seasonal-calendar approach, discussing subsistence activities performed and environmental disturbances encountered during every season within an annual cycle. Questions targeted both information regarding environmental disturbances encountered during the time frame of the study (12-month period) and broader local ecological knowledge regarding how landscape and subsistence behaviors had changed over time. Our semistructured interviews were designed to complement and allow direct comparisons with the GPS unit approach.

\section{Data analysis}

\section{Categorization of conditions}

We created categories of environmental conditions that were inclusive of the data harvesters collected, yet provided enough detail for meaningful analysis. Using GPS and interview data, we binned all observations into seven classes of environmental conditions (Fig. 2). These included: ice conditions, snow conditions, water levels, vegetative community composition, erosion, sedimentation, and weather. 
Fig. 2. Descriptions and photographic examples of the seven condition classes developed by researchers of conditions associated with environmental changes that were reported to affect access to subsistence resources.

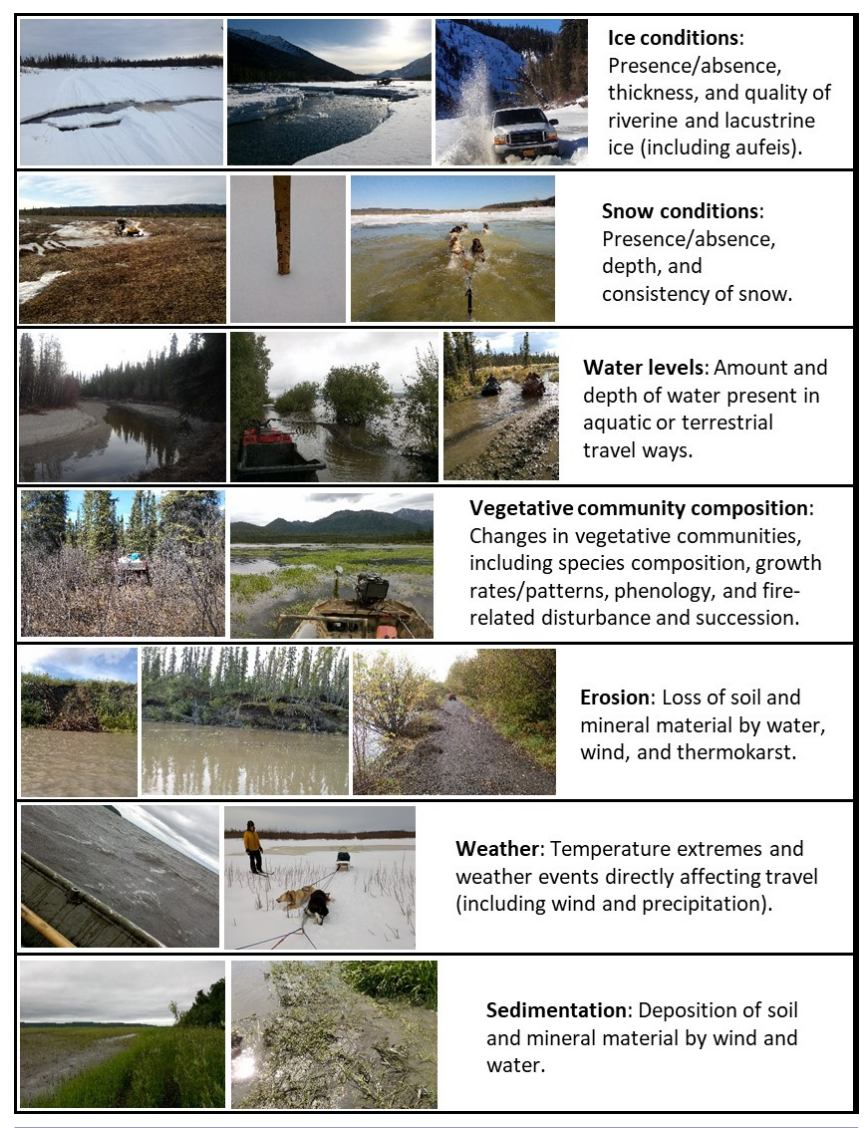

Vulnerability index

To better understand the relative impact that each condition had on access to subsistence resources, we used a vulnerability index to assess individual observations, e.g., GPS data point, and quantitative components of coded interview data. Vulnerability can be defined as the extent to which a system is unable to cope with adverse effects (IPCC 2001). Vulnerability indices have been used for risk analysis studies spanning many environmental science disciplines (Ford and Smit 2004, Fletcher 2005, Allison et al. 2009, Ford and Furgal 2009). Key parameters of vulnerability include the likelihood (frequency) that the system, e.g., person or community, is exposed, the sensitivity of a system to the stressor, and the adaptive capacity of the system (Adger 2006). Because the relationship among these components is highly context specific, it is important to carefully consider the analytical approach chosen to calculate vulnerability (Allison et al. 2009). For our study, we calculated vulnerability values (V) for each of the seven environmental condition classes as the sum of the likelihood ( $\mathrm{Li}$ ) that a harvester would experience a condition and the sensitivity (S) of the activity to the presence of the condition.

$$
\mathrm{V}=\mathrm{Li}+\mathrm{S}
$$

We decided on additive (Adger and Vincent 2005) rather than multiplicative (Allison et al. 2009) interactions between parameters to equally weight likelihood and sensitivity. A multiplicative approach would allow an extremely low or high value for either component to disproportionately influence final vulnerability values. For our analyses, $\mathrm{Li}$ was equal to the number of times an environmental condition was documented over the course of the study. For S, we developed a 7-point scale that considered the implications of the condition encountered on the subsistence activity in which the harvester was engaged, and the effect that each condition had on harvester travel efficiency, safety, and the opportunity to harvest resources (Table 1). This metric incorporated the adaptive capacity of individuals to environmental conditions, as their reporting included contextual information regarding their ability to adapt to stressors associated with each condition. Information used to develop the scale was extracted from responses to interview questions and data collected on GPS data forms. We normalized the likelihood and the 7-point sensitivity scale values $(0-1)$ to ensure that both values would be of equal weight when computing the final vulnerability value. When considering the normalized scale, likelihood values between 0 and 0.5 have positive outcomes on travel and access, and values between 0.5 and 1 have negative outcomes. Higher vulnerability values $(\mathrm{Li}+\mathrm{S}$, range of $0-2)$ indicate greater vulnerability to a condition during the entire study period.

Table 1. Components of vulnerability index equation used to rank effects of environmental conditions on travel and access to natural resource use areas.

\begin{tabular}{|c|c|}
\hline Sensit & Des \\
\hline 1.00 & $\begin{array}{l}\text { ity, forces serious sacrifices, prevents needs being } \\
\text { g negative effect on safety. }\end{array}$ \\
\hline 0.83 & $\begin{array}{l}\text { Involves challenges including increased time, energy, and } \\
\text { financial expenditures. Reduced harvest opportunity, negative } \\
\text { effect on safety. }\end{array}$ \\
\hline 0.67 & $\begin{array}{l}\text { Activity performed, some forced change of plans or strategy. } \\
\text { Minimal loss in opportunity, slight negative effect on safety. }\end{array}$ \\
\hline 0.50 & No net effect on opportunity or safety. \\
\hline 0.33 & $\begin{array}{l}\text { e than normal. Slight gain in } \\
\text { on safety. }\end{array}$ \\
\hline 0.17 & $\begin{array}{l}\text { Creates additional opportunity, including decreased time, } \\
\text { energy, and financial expenditures. Increased harvest } \\
\text { opportunity, positive effect on safety. }\end{array}$ \\
\hline 0.00 & $\begin{array}{l}\text { Greatly enhances activity, enables abnormally efficient travel } \\
\text { and access, and enhances ability to meet needs. Strong positive } \\
\text { effect on safety. }\end{array}$ \\
\hline
\end{tabular}

Although we analyzed both GPS and interview data using our vulnerability index, each data set required different strategies for preliminary analysis. GPS-based observations and data from the forms harvesters completed in association with each photo facilitated assignment of sensitivity values to each observed condition. For each harvester, we calculated an overall sensitivity value for each condition by calculating the weighted average of sensitivity values for all observations of that condition (Table 2). We used proportional values to calculate likelihood $(\mathrm{Li})$ for each condition category, which involved dividing the number of data points within a condition per harvester by the total number of points collected by a harvester rather than a count of the number of times a harvester documented a condition. Using proportional 
values in lieu of a count allowed for direct comparisons of vulnerability among harvesters, regardless of the number of observations each individual contributed. Values calculated for sensitivity and likelihood were summed to determine final vulnerability values for each condition documented by each harvester (Table 2). Vulnerability values for each condition were calculated for each community by averaging the vulnerability values calculated for each harvester within that community. We also compared observations from road-connected communities to those from remote communities to identify potential differences in vulnerability of access by either group to environmental conditions. For these analyses, we averaged community vulnerability values for each condition for roadconnected and remote communities. A visual example of analysis groupings (among harvesters, among all communities, and comparing remote versus road-accessible communities) is illustrated in Figure 3.

Table 2. Example of how final vulnerability value was calculated for a single condition (ice conditions) documented by a single harvester during the 12-month GPS data collection period.

\begin{tabular}{lccccc}
\hline \hline Condition & $\begin{array}{c}\text { Sensitivity } \\
\text { Category }\end{array}$ & $\begin{array}{c}\text { Number } \\
\text { of } \\
\text { Observati- } \\
\text { ons }\end{array}$ & $\begin{array}{c}\text { Decimal } \\
\text { of Total }\end{array}$ & $\begin{array}{c}\text { Sensitivity } \\
\text { Value }\end{array}$ & $\begin{array}{c}\text { Vulnerability } \\
\text { Value }\end{array}$ \\
\hline Ice & \multicolumn{7}{c}{ Conditions } & 0.83 & 15 & 0.01 & 2.00 & 2.01 \\
& 0.67 & 5 & 0.11 & 12.50 & 12.61 \\
& 0.50 & 0 & 0.04 & 3.33 & 3.37 \\
& 0.33 & 0 & 0.00 & 0.00 & 0.00 \\
& 0.17 & 0 & 0.00 & 0.00 & 0.00 \\
Totals & 0.00 & 0 & 0.00 & 0.00 & 0.00 \\
& & 22.00 & 0.16 & 0.81 & 0.97 \\
\hline
\end{tabular}

We developed a coding structure to extract data from interview transcripts. Coding is a commonly used technique for the analysis of qualitative data present in interviews, and involves assigning meaning to descriptive or inferential information gathered in a study (Huberman and Miles 1994). We coded transcribed interviews using software ATLAS.ti (Scientific Software Development $\mathrm{GmbH}$, Berlin). We developed five code groups: Environmental Condition, Season, Subsistence Activity, Sensitivity Index Value, and Adaptive Response. Environmental Condition, Subsistence Activity, and Adaptive Response all extracted contextual information that was also captured on data forms associated with GPS photos. We calculated likelihood of encountering an environmental condition by summing the number of times a condition was mentioned during an interview, resulting in a single value for each environmental condition at the individual harvester level. This summed likelihood value for an individual condition was compared to other conditions and assigned a relative normalized value between 0 and 1 . We assigned sensitivity values to conditions at the harvester level following criteria from the same 7-point scale used in the GPS approach (Table 1). Whenever likelihood and sensitivity values were associated with the same condition observation during the coding process, we considered that association a data point similar to each observation documented with GPS units. Identical to the GPS approach, we used sensitivity and likelihood values to calculate vulnerability index values for each environmental condition at the harvester level. The parallel designs in analysis between the GPS and semistructured interview approaches facilitated both a direct comparison and a merging of data from both approaches into a single vulnerability analysis. We averaged vulnerability values for both data sets for each environmental condition to determine vulnerability values for the combined datasets. When either GPS or interview data was lacking from a particular individual or community, we used the single data set to represent vulnerability values for conditions. Merging the two datasets provided the opportunity to understand the relative influence of differences in analysis results for each, and potentially give a more holistic view of the effects of changes in environmental conditions over time.

\section{Statistical analysis}

For the merged GPS and interview data, we tested for differences in mean vulnerability values among environmental conditions and between community types (road vs. remote) using a one-way analysis of variance (ANOVA). We used Games-Howell Post Hoc Test (Toothaker 1993) to explore differences between individual environmental conditions because of unequal samples sizes. Vulnerability values were log transformed to meet assumptions of normality. We used a Levene statistic to test for homogeneity of variances. An F test with a significance value of $\leq 0.05$ indicated that mean vulnerability values were not equal across community type or condition. We used General Linear Model (GLM) univariate procedure to estimate the amount of variation in vulnerability value explained by different models. We explored four models: (1) condition, (2) community type, (3) condition + community type, and (4) condition + community type + condition * community type. Model performance was based on adjusted Rsquared value; the amount of variation in vulnerability value explained by the predictor variables. We used the partial eta squared statistic to determine the effect size of terms, e.g., condition, in the models (Cohen 1973). Larger values of the partial eta squared indicate a greater amount of variation accounted for by the model effect, to a maximum of 1 .

\section{RESULTS}

Among the nine communities collaborating with this research, 18 harvesters documented 479 individual observations of environmental conditions affecting their travel with GPS units (Table 3). We conducted comprehensive interviews with 22 harvesters across eight communities (Healy was not represented) and extracted 294 data points containing likelihood and sensitivity data for environmental conditions affecting access to subsistence resources by project participants (Table 3 ).

Using the most comprehensive dataset, i.e., combined GPS and interview data, we found that variances of mean vulnerability values were equal for environmental conditions $(P=0.27)$ and community type (road-connected vs. remote; $\mathrm{P}=0.42$ ). We found that mean vulnerability values differed among environmental conditions ( $\mathrm{df}=6, \mathrm{~F}=3.695, \mathrm{P}<0.01)$ and between community types $(\mathrm{df}=1, \mathrm{~F}=6.973, \mathrm{P}<0.01)$. Ranges (accounting for $95 \%$ confidence interval) of vulnerability values of environmental conditions often overlapped, with statistically significant differences present when comparing conditions with the highest vulnerability values to those with the lowest. The mean vulnerability value of ice conditions was similar to all other 
Fig. 3. Visual example of data groupings used for different analyses. Mean vulnerability values for each environmental condition were averaged to create an overall vulnerability value for individuals, for all communities combined, for road-connected communities combined, and for remote communities combined.

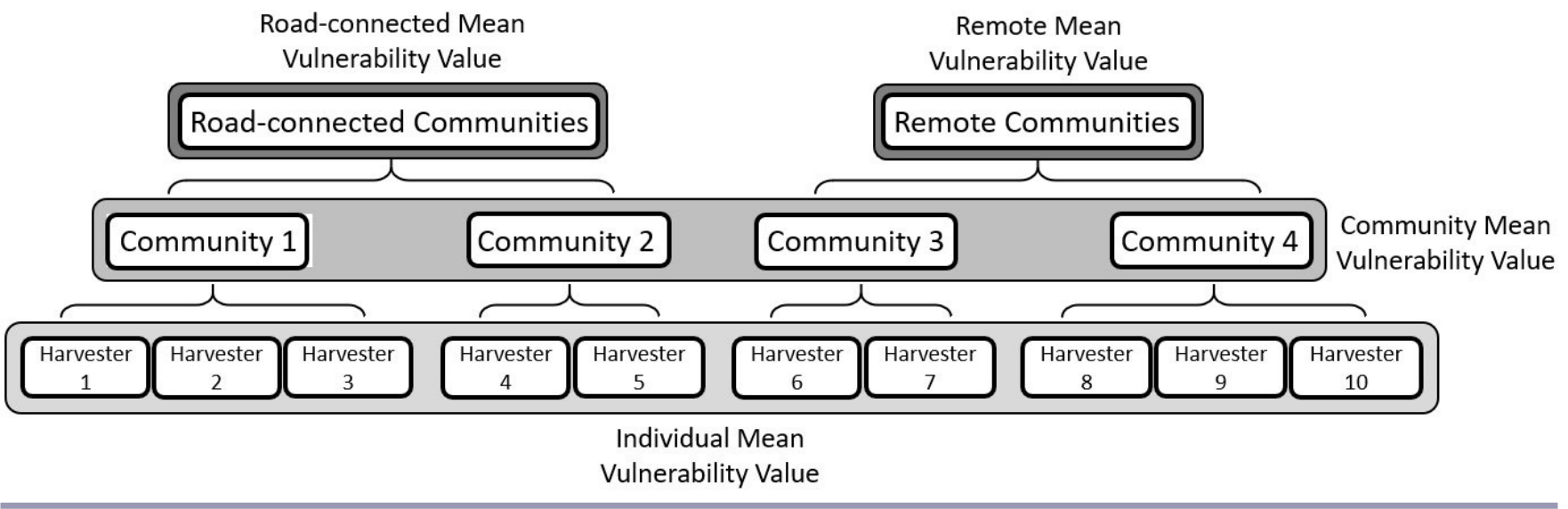

conditions except sedimentation $(\mathrm{P}<0.01)$ and weather $(\mathrm{P}<0.01)$ conditions. However, the mean vulnerability value of sedimentation was similar to all other conditions. Thus, the mean vulnerability value for weather conditions was lower than all other conditions except sedimentation $(\mathrm{P}=0.99)$. Low vulnerability to sedimentation and weather conditions was primarily caused by consistently low likelihood of encountering these conditions, rather than sensitivity to these conditions.

Table 3. Numbers of harvesters and GPS/interview observations documented for each collaborating community.

\begin{tabular}{lccccc}
\hline \hline Community & \multicolumn{2}{c}{ Number of Harvesters } & & Number of Observations \\
\cline { 2 - 3 } \cline { 5 - 6 } \cline { 5 - 6 } & GPS & Interviews & & GPS & Interviews \\
\hline Holy Cross & 2 & 2 & & 25 & 35 \\
Grayling & 1 & 3 & & 5 & 42 \\
Nulato & 2 & 6 & & 21 & 66 \\
Lake Minchumina & 2 & 2 & & 256 & 34 \\
Beaver & 3 & 3 & & 20 & 43 \\
Venetie & 3 & 3 & & 13 & 21 \\
Healy & 1 & 0 & & 9 & 0 \\
Delta Junction & 1 & 1 & & 17 & 24 \\
Tok & 3 & 2 & & 113 & 29 \\
Totals & 18 & 22 & & 479 & 294 \\
\hline
\end{tabular}

Our model that explained the most variation (adjusted R-squared $=0.18)$ in vulnerability included the main effects of condition and community type (road-connected vs. remote). Both condition ( $\mathrm{df}$ $=6, \mathrm{~F}=4.21, \mathrm{P}<0.01)$ and community type $(\mathrm{df}=1, \mathrm{~F}=9.53, \mathrm{P}$ $<0.01$ ) were significant terms in the model. Condition (Partial Eta Squared $=0.18$ ) had a larger effect on vulnerability than community type (Partial Eta Squared $=0.08$ ). The model that included condition and community type as an interaction term explained the second most variation (Adjusted R Squared $=0.15$ ), but the interaction term was not significant $(P=0.71)$.

Most environmental conditions documented were negatively affecting travel and access. We found that across all communities and for remote communities, ice conditions had the greatest influence on travel and access to subsistence resources (Fig. 4).
In many cases, harvesters indicated that water bodies were freezing later or not at all, and ice thickness has decreased in key travel areas along the Yukon River and other tributaries. A participant in Nulato described the impact that changing ice conditions had on their winter travel:

Fig. 4. Graph comparing vulnerability values and associated margins of error for environmental conditions from GPS and interview data among remote communities, road-connected communities, and all communities combined.

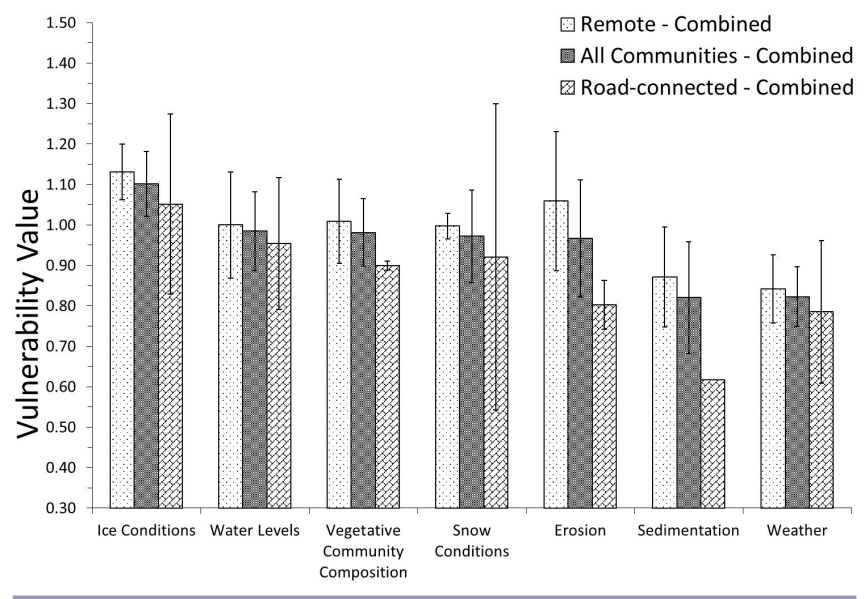

I snowmachine on the river and I go to Koyukuk, Galena, or Ruby, couple of trips to Huslia. And the one thing that Inotice is now I have to be really careful. Whereas I was just able to go by snowmachine (and) just follow the trail. not worry about holes or anything. But now I notice that it's starting to be later that we can begin traveling by snowmachine on the river. I used to travel before Thanksgiving and not worry about an open hole. And it used to be 20 below, sometimes 40 below, but now it's warmer. And you can travel only later on, around Christmas I'm going up now. 
Although all environmental conditions affected access to subsistence negatively overall, in some instances harvesters reported a positive relationship between conditions and access. Examples of this include low snow levels and high water levels increasing the accessibility by ATVs and boats, respectively. These observations emphasized the importance of context when interpreting the effects of changing environmental conditions on access.

\section{Road-connected vs remote communities}

Mean vulnerability values for all environmental conditions were lower in road-connected communities. For these locations, erosion had less of an impact on resource access than it did for remote communities (Fig. 4, Table A2.1). Although ice conditions were the most frequently reported condition in road-connected communities, sensitivity values of all conditions were again lowest for road-connected communities and highest for remote communities (Table A2.1). Vulnerability to vegetation was lower for road-connected communities and for GPS data as compared to interview data (Figs. A3.1, A3.2; Tables A3.1, A3.2). Interview data provided a longer term perspective on change as compared to GPS data. A project participant from Tok discussed how shifts in vegetation are increasingly becoming problematic when hunting:

... the first thing that comes to mind is the amount of
growth of brush. Ireally noticed trails or creeks we would
walk up to sheep hunting areas when I was a kid over 20
years ago, it was fairly mild. There were places where the
brush was just thick probably eons. But now days there's
some of those creeks that we used to traverse that it's
super thick. It's almost to the point where you should be
carrying a machete all the time. And even if we do and
you kind of chop out a trail it's growing back within two
years minimum. It grows back fast.

Snow conditions had the highest likelihood value and a relatively low sensitivity compared to all other conditions for roadconnected communities. Harvesters reported that although snow conditions did impact their abilities to travel and access resources, they were often able to conduct activities by adjusting the timing or location of resource harvest. Erosion had the lowest likelihood value in road-connected communities and moderate values in remote communities. A high sensitivity value for erosion compensated for lower likelihood values to allow that condition a high vulnerability value for the analysis for remote communities, whereas sensitivity to erosion was less impactful on access to resources for residents of road-connected communities (Fig. 4). Although erosion was reported less frequently during interviews and within road-connected communities (Fig. A3.2; Table A3.2), when it was encountered it posed substantial safety risks and access difficulties, resulting in high sensitivity values. Harvesters indicated that debris from eroding banks often decreased safety and damaged equipment used to harvest resources. One harvester from Nulato described how debris from erosion on the Yukon River near their home thwarted salmon fishing efforts for family and friends using fish wheel structures further downriver:

That's the main reason a majority of the wheels below us went. Because all the trees were floating down and they were floating into the wheels and busting up their baskets, busting up all of the braces, busting up the raft. It was horrible. Really horrible. It was really sad because a lot of these families depend on that for the winter. And it was frustrating a lot of the fishermen.

\section{DISCUSSION}

Our study provided several novel contributions on how climaterelated landscape changes affect access to local resources. First, we implemented a community-based research approach where rural residents documented specific environmental conditions that were important to them. Previous studies seldom generated both temporarily and spatially explicit information on the exact type of environmental condition challenging travel and access to local resources. Second, we provided quantitative estimates of the relative difference in rural community vulnerability to multiple environmental challenges. Nearly all previous research on this topic has been qualitative and ethnographic (Berkes and Jolly 2001, Kofinas et al. 2010, Moerlein and Carothers 2012). Our study approach can be applied to assess vulnerability to other stressors and regions.

In general, the environmental changes documented in our study reflect the close association between subsistence activities and frozen water corridors in northern latitudes (Berman and Kofinas 2004, Prowse et al. 2007, Johnson et al. 2016). Supported by previous research on both sea (Laidler 2007, Laidler et al. 2009, Prowse et al. 2011) and inland ice (Schneider et al. 2013), our results indicated high vulnerability to dynamic ice conditions. Winter temperatures in Interior Alaska have warmed more dramatically than any other season, fostering instability and unpredictability in winter ice (Wendler and Shulski 2009). These conditions create safety concerns, a shorter navigable window for travel, and often cause delays in travel because of the need to wait to conduct an activity until environmental conditions became more favorable (Brown et al. 2018).

We also found that rural Interior Alaskan communities were vulnerable to changes in water levels, erosion, and vegetative community composition, and to a lesser degree sedimentation and weather. Similar to other findings (Hasbrouck 2018), we found that high water levels were generally associated with increased access to harvest and hunting areas along major rivers and low water made travel difficult or impossible in many lakes, rivers, and streams. Erosion along river or lake banks can result in physical inaccessibility of travel corridors (Kanevskiy et al. 2016, Payne et al. 2018), but also rapidly alters the quality of fishing locations. Debris eroded in the water makes setting and maintaining fishing equipment challenging. Rural communities are particularly vulnerable to changes in waterways when roads are few or absent. The encroachment and change of abundance of woody vegetation, e.g., shrubification, in northern latitudes over the last 30-50 years is fairly well documented (Pearson et al. 2013, IPCC 2014), and these shifts are anticipated to continue for the next 50 years if growing conditions remain favorable (Tape et al. 2006, Myers-Smith et al. 2018). These changes in plant community composition and structure make maintaining trails and remote airfields more difficult (McNeely and Shulski 2011). Harvesters from our study confirmed that changes in vegetation either directly via increases in biomass or indirectly through wildfire disturbance and permafrost thaw create vulnerability for rural communities in Alaska. It was somewhat surprising that vulnerability to both sedimentation and weather was minimal. 
Compared to other disturbance categories, sedimentation is a more localized event encountered in a few areas with specific landscape characteristics, e.g., confluence of tributaries or flood prone patches, rather than ubiquitous environmental change. In contrast, weather is a widespread phenomenon; however, we speculate that Interior Alaska is more buffered from the effects of extreme weather than coastal communities that need calm seas for travel (Hansen et al. 2013). Modern mechanical equipment used to access subsistence harvest areas (snowmachines, motorboats, ATVs) may be more resilient to harsh conditions than historical modes of transport (canoes, dog teams; Brinkman et al. 2014). Also, weather can be forecasted, which may assist rural residents with planning before they travel.

Our results suggest that remote communities are more vulnerable than road-connected communities to all environmental conditions encountered, especially ice conditions and erosion. Access to road networks appears to influence both the kinds of environmental conditions that communities are vulnerable to, and the degree to which they are vulnerable. This phenomenon may be linked to differences in extent of reliance of natural corridors between remote and road-connected communities (Carothers et al. 2014, Brinkman et al. 2016; J. S. Magdanz et al. 2016, unpublished manuscript). Road-connected communities have a greater number of transportation options than remote communities because they can use both the natural travel corridors and the often extensive road and trail systems accessible in more developed areas. Additionally, the effects of similar environmental conditions may differ depending on mode of transportation used. During our interviews, several harvesters from road-connected communities described situations where high water would be detrimental to vehicular crossing of a water body. In contrast, high water was often described as a favorable travel condition for participants in remote communities that used watercraft.

We found that the range of vulnerability values for all environmental conditions was greater for GPS data than interview data, which could be indicative of possible limitations in the GPS data. During the GPS data collection period (March 2016-June 2017), harvesters occasionally reported environmental conditions that were so severe that they did not even attempt to conduct a certain subsistence activity, and therefore were unable to collect photo documentation of the condition. This resulted in gaps in data that could be interpreted very differently if no context was provided because it could signify that an activity was either (1) not affected and therefore no conditions were documented, or (2) the current conditions were so extreme that they caused a cessation in attempts to conduct the activity. GPS data may, therefore, underrepresent water levels, ice conditions, and snow conditions because of the occasional extreme nature of these events inhibiting normal subsistence activities. In these cases, coded interview data may present a broader picture of the relative effects of environmental disturbance over the entire calendar year. Additionally, it may be that when asked to report environmental conditions encountered in the moment with GPS units, harvesters were more likely to report instantaneous "pulse" changes than sustained "press" changes (Bender et. al 1984, Collins et al. 2011). It is plausible that pulse events such as erosion are more immediately visible when compared to normal conditions, which may have increased the likelihood that they would be reported.
In contrast, changes in vegetative community composition happened at a comparatively slower pace, which may be elaborated on during interviews when respondents reflect on nontemporally explicit changes over their lifetimes. We speculate that merging GPS with interview data provided the most comprehensive and accurate overall assessment of rural resident vulnerability to environmental conditions. Because of the complementary nature of GPS and interview data, we recommend that future research merge methodologies to address gaps and incorporate strengths of each approach.

We acknowledge that the environmental conditions documented by subsistence harvesters are interrelated rather than independent and mutually exclusive. We attempted to create discrete environmental condition categories by distinguishing causes (the processes that lead to the presence of a condition on the landscape) from effects (the result of a process, which represents the actual on-the-ground situation affecting travel and access for the harvester). However, a network of relationships exists among causes and effects. For example, Brown et al. (2018) described how long-term changes in mean air temperature have contributed to variation in freeze-up and break-up dates, i.e., ultimate cause, on the Yukon River, and how those changes are affecting river travel, i.e., proximate effect, for rural communities. Another example includes the potential impact of wildfires in Alaska on the hydrology, permafrost extent, and changes in vegetation communities. These environmental changes might influence travel and access to subsistence resources through physical obstruction by regenerating vegetation (Huntington and Fox 2005, McNeeley and Shulski 2011, Johnson et al. 2016), land slumping and riverbank erosion related to permafrost degradation (Hinzman et al. 2005, Moerlein and Carothers 2012), and increasing prevalence of toppled trees and ground slash that obstruct trail networks (Nelson et al. 2008, Brinkman et al. 2016). Therefore, although we can determine that some conditions are more deleterious to subsistence resource access, further investigating the relationship between ultimate cause and proximate effect will ultimately aid prioritizing efforts by communities and agencies to adapt to changing conditions.

Our research provides insight on the relative, rather than actual, vulnerability of a specific individual or community to a specific change. This distinction is important, because measuring the actual societal consequences of restricted access on rural communities would involve further investigation on the cultural and economic aspects of the wide array of subsistence activities. For example, although the trapping season and trapping locations for furbearers may be greatly reduced in some years because of unfavorable ice conditions, perhaps those harvesters are able to compensate for the lack of expected income by harvesting another resource (such as firewood) or obtaining wage employment (Hansen et. al 2013). However, because financial gain is rarely the sole factor driving subsistence engagement, the social impacts of reduced participation in subsistence warrants equal consideration (Kruse 1991). Additionally, most harvesters participating in this research represented those individuals that had the heaviest involvement in subsistence activities, and their behaviors do not necessarily represent the community. Although subsistence activities play a role in the economies and cultures of most rural communities to some degree (Wolfe and Walker 1987), the importance of subsistence as a whole and by individual activity 
varies greatly by location. Future research could use the results to prioritize and intensively pursue narrower questions that focus on specific aspects of vulnerability to changing environmental conditions. Such studies could investigate criteria that may differ by community, including predominant subsistence activities, specific resource types (moose, salmon, waterfowl, etc.), and modes of travel used to access resources. Parallel research concerning the economic and cultural implications of these effects would provide a holistic understanding of the actual vulnerability of communities to environmental change.

\section{CONCLUSIONS}

Identifying environmental conditions that have the greatest effects on travel and access to subsistence resources by rural residents of Interior Alaska provides information that residents can use to evolve adaptive solutions. Because climate warming is projected to continue at a relatively rapid rate (IPCC 2014), further environmental challenges are likely, and communities reliant on wild foods may face food security issues. Our research illustrated that environmental changes created challenges for rural residents in accessing subsistence resources, and the relative impacts of different types of conditions on resource access. Changes in environmental conditions not only reduce access to resources, but can also create problems using traditional gear and harvest methods, and complicate food processing and storing methods (Loring and Gerlach 2009, Sundkvist et al. 2005). Some project participants described steps they are taking to address challenges, such as changing the timing of harvest, mode of transportation, and travel route taken to harvest specific resources. However, in many cases social, economic, and regulatory obstacles impede efforts to adapt to challenges. Studies such as ours provide information that communities could use to advocate for policy changes that may address some of these issues. For example, subsistence harvests of Chinook salmon are subject to fishing closures along various portions of the Yukon River and its tributaries when it is projected that escapement goals will not be met. This often leaves rural residents with a narrow window to harvest salmon (Loring and Gerlach 2010), and encountering unfavorable environmental conditions during that time (such as changes in water levels or increased erosion) can further limit harvest success. Considering the effect of local environmental conditions on harvest success of subsistence resources when creating and enacting regulatory controls may allow for successful subsistence harvest by rural residents that coincides with necessary resource management practices. Scientific efforts to model future environmental change could incorporate our data into climate models, and potentially predict how the landscape will continue to change over time and the societal consequences of changing human access to ecosystem services. This knowledge can support community identification of subsistence harvest areas vulnerable to future change and guide proactive planning.

Responses to this article can be read online at: http://www.ecologyandsociety.org/issues/responses. $\mathrm{php} / 11426$

\section{Acknowledgments:}

The authors would like to thank the NASA ABoVE program (NASA: NNX15AT72A) and the National Science Foundation (NSF: 1518563) for their financial support. We would also like to thank our research collaborators, including the Council of Athabascan Tribal Governments, The Alaska Department of Fish and Game Division of Subsistence, and the communities of Beaver, Delta Junction, Grayling, Healy, Holy Cross, Lake Minchumina, Nulato, Tok, and Venetie.

\section{LITERATURE CITED}

Adger, W. N. 2006. Vulnerability. Global Environmental Change 16(3):268-281. https://doi.org/10.1016/j.gloenvcha.2006.02.006

Adger, W. N., and K. Vincent. 2005. Uncertainty in adaptive capacity. Comptes Rendus Geoscience 337(4):399-410. https://doi. org/10.1016/j.crte.2004.11.004

Allison, E. H., A. L. Perry, M. C. Badjeck, W. N. Adger, K. Brown, D. Conway, A. S. Halls, G. M. Pilling, J. D. Reynolds, N. L. Andrew, and N. K. Dulvy. 2009. Vulnerability of national economies to the impacts of climate change on fisheries. Fish and Fisheries 10(2):173-196. https://doi.org/10.1111/j.1467-2979.2008.00310. $\underline{x}$

Bender, E. A., T. J. Case, and M. E. Gilpin. 1984. Perturbation experiments in community ecology: theory and practice. Ecology 65(1):1-13. https://doi.org/10.2307/1939452

Berkes, F., and D. Jolly. 2001. Adapting to climate change: socialecological resilience in a Canadian western Arctic community. Ecology and Society 5(2):18. https://doi.org/10.5751/ES-00342-050218

Berman, M., and G. Kofinas. 2004. Hunting for models: grounded and rational choice approaches to analyzing climate effects on subsistence hunting in an Arctic community. Ecological Economics 49(1):31-46. https://doi.org/10.1016/j.ecolecon.2003.12.005

Bieniek, P. A., J. E. Walsh, R. L. Thoman, and U. S. Bhatt. 2014. Using climate divisions to analyze variations and trends in Alaska temperature and precipitation. Journal of Climate 27 (8):2800-2818. https://doi.org/10.1175/JCLI-D-13-00342.1

Brabets, T. P., B. Wang, and R. H. Meade. 2000. Environmental and hydrologic overview of the Yukon River basin, Alaska and Canada. Water-Resources Investigations Report 99-4204. U.S. Geological Survey, Anchorage, Alaska, USA. https://doi. org/10.3133/wri994204

Brinkman, T., K. B. Maracle, J. Kelly, M. Vandyke, A. Firmin, and A. Springsteen. 2014. Impact of fuel costs on high-latitude subsistence activities. Ecology and Society 19(4):18. https://doi. org/10.5751/ES-06861-190418

Brinkman, T. J., W. D. Hansen, F. S. Chapin, G. Kofinas, S. BurnSilver, and T. S. Rupp. 2016. Arctic communities perceive climate impacts on access as a critical challenge to availability of subsistence resources. Climatic Change 139(3-4):413-427. https:// doi.org/10.1007/s10584-016-1819-6

Brown, C. L., A. Brenner, H. Ikuta, E. H. Mikow, B. Retherford, L. J. Slayton, A. Trainor, J. Park, D. Koster, and M. L. Kostick. 
2015. The harvest ad uses of wild resources in Mountain Village, Marshall, Nulato, Galena, and Ruby, Alaska, 2010. Technical Paper No. 410. Alaska Department of Fish and Game, Division of Subsistence, Fairbanks, Alaska, USA.

Brown, D. R., T. J. Brinkman, D. L. Verbyla, C. L. Brown, H. S. Cold, and T. N. Hollingsworth. 2018. Changing river ice seasonality and impacts on Interior Alaskan communities. Weather, Climate and Society 10:625-640. https://doi.org/10.1175/ WCAS-D-17-0101.1

Brubaker, M., J. Berner, R. Chavan, and J. Warren. 2011. Climate change and health effects in Northwest Alaska. Global Health Action 4:8445. http://doi.org/10.3402/gha.v4i0.8445

Carothers, C., C. Brown, K. J. Moerlein, J. Andrés López, D. B. Andersen, and B. Retherford. 2014. Measuring perceptions of climate change in northern Alaska: pairing ethnography with cultural consensus analysis. Ecology and Society 19(4):27. https:// doi.org/10.5751/ES-06913-190427

Clark, D. G., J. D. Ford, L. Berrang-Ford, T. Pearce, S. Kowal, and W. A. Gough. 2016. The role of environmental factors in search and rescue incidents in Nunavut, Canada. Public Health 137:44-49. https://doi.org/10.1016/j.puhe.2016.06.003

Cohen, J. 1973. Eta-squared and partial eta-squared in fixed factor ANOVA designs. Educational and Psychological Measurement 33(1):107-112. https://doi.org/10.1177/001316447303300111

Collins, S. L., S. R. Carpenter, S. M. Swinton, D. E. Orenstein, D. L. Childers, T. L. Gragson, N. B. Grimm, J. M. Grove, S. L. Harlan, J. P. Kaye, et al. 2011. An integrated conceptual framework for long-term social-ecological research. Frontiers in Ecology and the Environment 9(6):351-357. https://doi. org/10.1890/100068

Conrad, C. C., and K. G. Hilchey. 2011. A review of citizen science and community-based environmental monitoring: issues and opportunities. Environmental Monitoring and Assessment 176 (1-4):273-291. https://doi.org/10.1007/s10661-010-1582-5

Driscoll, D. L., E. Mitchell, R. Barker, J. M. Johnston, and S. Renes. 2016. Assessing the health effects of climate change in Alaska with community-based surveillance. Climatic Change 137 (3-4):455-466. https://doi.org/10.1007/s10584-016-1687-0

Fall, J. A. 2018. Subsistence in Alaska: a year 2017 update. Alaska Department of Fish and Game Division of Subsistence, Special Publication, Anchorage, Alaska, USA. [online] URL: http:// www.adfg.alaska.gov/static/home/subsistence/pdfs/ subsistence update 2017.pdf

Fall, J. A., and M. L. Kostick. 2018. Food security and wild resource harvests in Alaska. Alaska Department of Fish and Game Division of Subsistence, Special Publication, Anchorage, Alaska, USA. [online] URL: http://www.adfg.alaska.gov/static/home/ subsistence/pdfs/food security whitepaper.pdf

Fletcher, W. J. 2005. The application of qualitative risk assessment methodology to prioritize issues for fisheries management. ICES Journal of Marine Science 62(8):1576-1587. https://doi. org/10.1016/j.icesjms.2005.06.005

Ford, J. D., and C. Furgal. 2009. Foreword to the special issue: Climate change impacts, adaptation and vulnerability in the
Arctic. Polar Research 28(1):1-9. https://doi.org/10.1111/ j.1751-8369.2009.00103.x

Ford, J. D., and T. Pearce. 2012. Climate change vulnerability and adaptation research focusing on the Inuit subsistence sector in Canada: directions for future research. Canadian Geographer 56 (2):275-287. https://doi.org/10.1111/j.1541-0064.2012.00418.x

Ford, J. D., and B. Smit. 2004. A framework for assessing the vulnerability of communities in the Canadian Arctic to risks associated with climate change. Arctic 57(4):325-454. https://doi. org/10.14430/arctic516

Goldsmith, S. 2007. The remote rural economy of Alaska. Institute of Social and Economic Research, University of Alaska Anchorage, Anchorage, Alaska, USA. [online] URL: https:// iseralaska.org/static/legacy publication links/u ak/ uak remoteruraleconomyak.pdf

Hansen, W. D., T. J. Brinkman, F. S. Chapin III, and C. Brown. 2013. Meeting indigenous subsistence needs: the case for prey switching in rural Alaska. Human Dimensions of Wildlife 18 (2):109-123. https://doi.org/10.1080/10871209.2012.719172

Hansen, W. D., T. J. Brinkman, M. Leonawicz, F. S. Chapin III, and G. P. Kofinas. 2013. Changing daily wind speeds on Alaska's North Slope: implications for rural hunting opportunities. Arctic 66(4):389-527. https://doi.org/10.14430/arctic4331

Hasbrouck, T. R. 2018. Distribution of hunter groups and environmental effects on moose harvest in Interior Alaska. Thesis. University of Alaska Fairbanks, USA. [online] URL: https:// search.proquest.com/openview/50a67a6162db827ab5ce49391c664b09/1. pdf?pq-origsite $=$ gscholar $\& \mathrm{cbl}=18750 \&$ diss $=\mathrm{y}$

Hinzman, L. D., N. D. Bettez, W. R. Bolton, F. S. Chapin, M. B. Dyurgerov, C. L. Fastie, B. Griffith, R. D. Hollister, A. Hope, H. P. Huntington, A. M. Jensen, G. J. Jia, T. Jorgenson, D. L. Kane, D. R. Klein, G. Kofinas, A. H. Lynch, A. H. Lloyd, A. D. McGuire, F. E. Nelson, W. C. Oechel, T. E. Osterkamp, C. H. Racine, V. E. Romanovsky, R. S. Stone, D. A. Stow, M. Sturm, C. E. Tweedie, G. L. Vourlitis, M. D. Walker, D. A. Walker, P. J. Webber, J. M. Welker, K. S. Winker, and K. Yoshikawa. 2005. Evidence and implications of recent climate change in Northern Alaska and other Arctic regions. Climatic Change 72(3):251-298. https://doi.org/10.1007/s10584-005-5352-2

Holen, D., S. M. Hazell, and D. S. Koster, editors. 2012. Subsistence harvests and uses of wild resources by communities in the eastern Interior of Alaska, 2011. Technical Paper No. 372. Alaska Department of Fish and Game Division of Subsistence, Anchorage, Alaska, USA.

Holen, D. L., W. E. Simeone, and L. Williams. 2006. Wild resource harvests and uses by residents of Lake Minchumina and Nikolai Alaska, 2001-2002. Technical Paper No. 296. Alaska Department of Fish and Game, Juneau, Alaska, USA.

Huberman, A. M., and M. B. Miles. 1994. Data management and analysis methods. Pages 428-444 in N. K. Denzin and Y. S. Lincoln, editors. Handbook of qualitative research. SAGE, Thousand Oaks, California, USA.

Huntington, H. P. 2000. Using traditional ecological knowledge in science: methods and applications. Ecological Applications 10 
(5):1270-1274. https://doi.org/10.1890/1051-0761(2000)010[1270: UTEKIS]2.0.CO;2

Huntington, H., and S. Fox. 2005. The changing Arctic: indigenous perspectives. Pages 61-98 in Arctic climate impact assessment. Cambridge University Press, Cambridge, UK.

Ikuta, H., C. L. Brown, and D. S. Koster, editors. 2014. Subsistence harvests in 8 Communities in the Kuskokwim River Drainiage and Lower Yukon River, 2011. Technical Paper No. 396. Alaska Department of Fish and Game, Division of Subsistence, Fairbanks, Alaska, USA.

Intergovernmental Panel on Climate Change (IPCC). 2001. Climate change 2001: impacts, adaptation, and vulnerability. Contribution of Working Group II to the Third Assessment Report of the Intergovernmental Panel on Climate Change. J. J. McCarthy, O. F. Canziani, D. J. Leary, D. J. Dokken, and K. S. White, editors. Cambridge University Press, Cambridge, UK

Intergovernmental Panel on Climate Change (IPCC). 2014. Climate change 2014: mitigation of climate change. Contribution of Working Group III to the Fifth Assessment Report of the Intergovernmental Panel on Climate Change. O. Edenhofer, R. Pichs-Madruga, Y. Sokona, E. Farahani, S. Kadner, K. Seyboth, A. Adler, I. Baum, S. Brunner, P. Eickemeier, B. Kriemann, J. Savolainen, S. Schlömer, C. von Stechow, T. Zwickel and J. C. Minx, editors. Cambridge University Press, Cambridge, UK.

Johnson, I., T. Brinkman, K. Britton, J. Kelly, K. Hundertmark, B. Lake, and D. Verbyla. 2016. Quantifying rural hunter access in Alaska. Human Dimensions of Wildlife 21(3):240-253. https:// doi.org/10.1080/10871209.2016.1137109

Johnson, N., L. Alessa, C. Behe, F. Danielsen, S. Gearheard, V. Gofman-Wallingford, A. Kliskey, E. M. Krümmel, A. Lynch, T. Mustonen, P. Pulsifer, and M. Svoboda. 2015. The contributions of community-based monitoring and traditional knowledge to Arctic observing networks: reflections on the state of the field. Arctic 68(5):1-13. https://doi.org/10.14430/arctic4447

Kanevskiy, M., Y. Shur, J. Strauss, T. Jorgenson, D. Fortier, E. Stephani, and A. Vasiliev. 2016. Patterns and rates of riverbank erosion involving ice-rich permafrost (yedoma) in northern Alaska. Geomorphology 253:370-384. https://doi.org/10.1016/j. geomorph.2015.10.023

Kofinas, G. P., F. S. Chapin, S. BurnSilver, J. I. Schmidt, N. L. Fresco, K. Kielland, S. Martin, A. Springsteen, and T. S. Rupp. 2010. Resilience of Athabascan subsistence systems to interior Alaska's changing climate. Canadian Journal of Forest Research 40(7):1347-1359. https://doi.org/10.1139/x10-108

Kruse, J. 1991. Alaska Inupiat subsistence and wage employment patterns: understanding individual choice. Human Organization 50(4):317-326. https://doi.org/10.17730/humo.50.4.c288gt2641286g71

Laidler, G. J. 2007. Ice, through Inuit eyes: characterizing the importance of sea ice processes, use, and change around three Nunavut communities. Geography 68(6-A).

Laidler, G. J., J. D. Ford, W. A. Gough, T. Ikummaq, A. S. Gagnon, S. Kowal, K. Qrunnut, and C. Irngaut. 2009. Travelling and hunting in a changing Arctic: assessing Inuit vulnerability to sea ice change in Igloolik, Nunavut. Climatic Change 94 (3-4):363-397. https://doi.org/10.1007/s10584-008-9512-z
Loring, P. A. and S. C. Gerlach. 2009. Food, culture and human health in Alaska: an integrative health approach to food security. Environmental Science and Policy 12(4):466-478. https://doi. org/10.1016/j.envsci.2008.10.006

Loring, P. A., and C. Gerlach. 2010. Food security and conservation of Yukon River salmon: Are we asking too much of the Yukon river? Sustainability 2(9):2965-2987. https://doi. org/10.3390/su2092965

McNeeley, S. M., and M. D. Shulski. 2011. Anatomy of a closing window: vulnerability to changing seasonality in Interior Alaska. Global Environmental Change 21(2):464-473. https://doi. org/10.1016/j.gloenvcha.2011.02.003

Moerlein, K. J., and C. Carothers. 2012. Total environment of change: impacts of climate change and social transitions on subsistence fisheries in northwest Alaska. Ecology and Society 17 (1):10. https://doi.org/10.5751/ES-04543-170110

Myers-Smith, I. H., and D. S. Hik. 2018. Climate warming as a driver of tundra shrubline advance. Journal of Ecology 106 (2):547-560. https://doi.org/10.1111/1365-2745.12817

Nelson, J. L., E. S. Zavaleta, and F. S. Chapin III. 2008. Boreal fire effects on subsistence resources in Alaska and adjacent Canada. Ecosystems 11(1):156-171. https://doi.org/10.1007/ $\underline{\text { s10021-007-9114-Z }}$

Payne, C., S. Panda, and A. Prakash. 2018. Remote sensing of river erosion on the Colville River, North Slope Alaska. Remote Sensing 10(3):397. https://doi.org/10.3390/rs10030397

Pearce, T., J. Ford, A. C. Willox, and B. Smit. 2015. Inuit traditional ecological knowledge (TEK), subsistence hunting and adaptation to climate change in the Canadian Arctic. Arctic 68 (2):141-282. https://doi.org/10.14430/arctic4475

Pearson, R. G., S. J. Phillips, M. M. Loranty, P. S. A. Beck, T. Damoulas, S. J. Knight, and S. J. Goetz. 2013. Shifts in Arctic vegetation and associated feedbacks under climate change. Nature Climate Change 3:673-677. https://doi.org/10.1038/nclimate1858

Porter, J. R., L. Xie, A. J. Challinor, K. Cochrane, S. M. Howden, M. M. Iqbal, D. B. Lobell, and M. I. Travasso. 2014. Food security and food production systems. Pages 485-534 in C. B. Field, V. R. Barros, D. J. Dokken, K. J. Mach, M. D. Mastrandrea, T. E. Bilir, M. Chatterjee, K. L. Ebi, Y. O. Estrada, R. C. Genova, B. Girma, E. S. Kissel, A. N. Levy, S. MacCracken, P. R. Mastrandrea, and L. L. White, editors. Climate change 2014: impacts, adaptation and vulnerability. Part A: global and sectoral aspects. Contribution of Working Group II to the Fifth Assessment Report of the Intergovernmental Panel on Climate Change. Cambridge University Press, Cambridge, UK. https://doi.org/10.1017/ cbo9781107415379.012

Prowse, T., K. Alfredsen, S. Beltaos, B. R. Bonsal, W. B. Bowden, C. R. Duguay, A. Korhola, J. McNamara, W. F. Vincent, V. Vuglinsky, K. M. W. Anthony, and G. A. Weyhenmeyer. 2011. Effects of changes in arctic lake and river ice. Ambio 40 (SUPPL1):63-74. https://doi.org/10.1007/s13280-011-0217-6

Prowse, T. D., B. P. Bonsal, C. R. Duguay, D. O. Hessen, and V. S. Vuglinsky. 2007. River and lake ice. Pages 201-214 in Global outlook for ice and snow United Nations Environment Programme, Nairobi, Kenya. 
Schneider, W., K. Brewster, K. Kielland, and C. E. Jones. 2013. On dangerous ice: changing ice conditions on the Tanana River. Oral History Program, Elmer E. Ramuson Library and the Institute of Arctic Biology. University of Alaska Fairbanks, USA. [online] URL: https://jukebox.uaf.edu/site7/sites/default/files/ documents/Dangerous $\% 20$ Ice $\% 20$ web $\% 202013-08-07-A-1$.pdf

Sundkvist, A., R. Milestad, and A. Jansson. 2005. On the importance of tightening feedback loops for sustainable development of food systems. Food Policy 30(2):224-239. https:// doi.org/10.1016/j.foodpol.2005.02.003

Tape, K., M. Sturm, and C. Racine. 2006. The evidence for shrub expansion in northern Alaska and the Pan-Arctic. Global Change Biology 12(4):686-702. https://doi.org/10.1111/j.1365-2486.2006.01128. $\underline{\mathrm{x}}$

Toothaker, L. E. 1993. Multiple comparison procedures. SAGE, London, UK.

U.S. Census Bureau. 2016. Annual estimates of the resident population: April 1, 2010 to July 1, 2016. U.S. Census Bureau, Population Division, Washington, D.C., USA. [online] URL: https://data.census. gov/cedsci/table?q=All $\% 20$ places $\% 20 \mathrm{in} \%$ 20Alaska\&g $=0400000$ US02.160000\&layer $=$ place $\&$ hidePreview $=$ false $\&$ tid $=$ ACSDP5Y2016.DP05\&cid $=$ DP05 0001E $\&$ vintage $=2016$

U.S. Department of Agriculture, Economic Research Service. 2017. Food security in the U.S. Economic Research Service, Washington, D.C., USA. [online] URL: https://www.ers.usda. gov/topics/food-nutrition-assistance/food-security-in-the-us.

U.S. Global Change Research Program (USGCRP). 2018. Impacts, risks, and adaptation in the United States: Fourth National Climate Assessment, Volume II. U.S. Global Change Research Program, Washington, DC, USA. https://doi.org/10.7930/ NCA4.2018

Viereck, L. A., C. T. Dyrness, A. R. Batten, and K. J. Wenzlick. 1992. The Alaska vegetation classification. General Technical Report PNW-GTR-286. U.S. Forest Service, Pacific Northwest Research Station, Portland, Oregon, USA. https://doi. org/10.2737/PNW-GTR-286

Wendler, G., and M. Shulski. 2009. A century of climate change for Fairbanks, Alaska. Arctic 62(3):295-300. https://doi. org/10.14430/arctic149

Wolfe, R. J., and R. J. Walker. 1987. Subsistence economies in Alaska: productivity, geography, and development impacts. Arctic Anthropology 24(2):56-81. 
Appendix 1: NASA Mapping Project GPS data collection form.

NASA Mapping Project

Documenting conditions related to travel \& access to wild resources

Name:

Date:

Photo ID:

What is pictured?

How do these conditions influence travel or access to resources?

Trip purpose?

O Hunting

○ Gathering (wood,

o Other

O Fishing berries)

○ Trapping

○ Village travel

O Camp

How frequently have you observed this travel condition?

O Observed weekly

O Observed monthly

- Observed seasonally

- Observed yearly
O Observed every few years

- Observed every few decades

- Never observed before

○ Not applicable

What year did you first notice this change?

To what extent does this condition affect travel safety?

O Strong affect

- Moderate affect

- Weak affect

O No affect

How common is this condition occurring in other places around your community?

- This change is common, I see it everywhere.

O I have seen this change in some other areas.

- I haven't seen this change anywhere else. 
Appendix 2: Results of vulnerability analysis of combined GPS and interview data at the community, road-connected and remote levels.

Table A2.1. Mean values for vulnerability analysis of combined GPS and interview data at the community, road-connected and remote levels.

\begin{tabular}{|c|c|c|c|c|c|c|c|}
\hline Condition & $\begin{array}{c}\text { Analysis } \\
\text { Level }\end{array}$ & $\begin{array}{c}\text { Average } \\
\text { Likelihood (Li) }\end{array}$ & $\begin{array}{c}\text { Average } \\
\text { Sensitivity (S) }\end{array}$ & $\begin{array}{c}\text { Vulnerability } \\
(\mathrm{V})^{+}\end{array}$ & $\begin{array}{c}\text { Number of } \\
\text { Observations }\end{array}$ & $\begin{array}{l}\text { Margin } \\
\text { of Error }\end{array}$ & $\begin{array}{l}\text { V Value } \\
\text { Range }^{\S}\end{array}$ \\
\hline \multirow[t]{3}{*}{ Ice Conditions } & All Communities & 0.30 & 0.79 & 1.10 & 190 & 0.08 & $1.02-1.18^{\mathrm{a}}$ \\
\hline & Road-connected & 0.30 & 0.75 & 1.05 & 45 & 0.22 & $0.83-1.27^{\mathrm{abc}}$ \\
\hline & Remote & 0.31 & 0.83 & 1.13 & 145 & 0.07 & $1.06-1.2^{\mathrm{a}}$ \\
\hline \multirow[t]{3}{*}{ Erosion } & All Communities & 0.19 & 0.78 & 0.97 & 83 & 0.14 & $0.83-1.11^{\mathrm{abc}}$ \\
\hline & Road-connected & 0.08 & 0.73 & 0.80 & 7 & 0.06 & $0.74-0.86^{b}$ \\
\hline & Remote & 0.17 & 0.89 & 1.06 & 76 & 0.17 & $0.89-1.23^{\mathrm{ac}}$ \\
\hline \multirow[t]{3}{*}{ Water Levels } & All Communities & 0.26 & 0.73 & 0.98 & 160 & 0.10 & $0.88-1.08^{a c}$ \\
\hline & Road-connected & 0.25 & 0.71 & 0.95 & 47 & 0.16 & $0.79-1.11^{\mathrm{abc}}$ \\
\hline & Remote & 0.26 & 0.74 & 1.00 & 113 & 0.13 & $0.87-1.13^{\mathrm{ac}}$ \\
\hline \multirow[t]{3}{*}{ Snow Conditions } & All Communities & 0.25 & 0.72 & 0.97 & 158 & 0.11 & $0.86-1.08^{a b c}$ \\
\hline & Road-connected & 0.32 & 0.60 & 0.92 & 56 & 0.38 & $0.54-1.3^{a b c}$ \\
\hline & Remote & 0.21 & 0.78 & 1.00 & 102 & 0.03 & $0.97-1.03^{a}$ \\
\hline \multirow[t]{3}{*}{ Vegetative Community Composition } & All Communities & 0.21 & 0.76 & 0.98 & 110 & 0.08 & $0.9-1.06 a^{c}$ \\
\hline & Road-connected & 0.22 & 0.68 & 0.90 & 29 & 0.01 & $0.89-0.91^{c}$ \\
\hline & Remote & 0.21 & 0.80 & 1.01 & 81 & 0.10 & $0.91-1.11^{\mathrm{ac}}$ \\
\hline \multirow[t]{3}{*}{ Sedimentation } & All Communities & 0.13 & 0.72 & 0.82 & 38 & 0.14 & $0.68-0.96^{b c}$ \\
\hline & Road-connected & 0.12 & 0.50 & 0.62 & 2 & N/A & N/A \\
\hline & Remote & 0.13 & 0.74 & 0.87 & 36 & 0.12 & $0.75-0.99^{b c}$ \\
\hline \multirow[t]{3}{*}{ Weather } & All Communities & 0.10 & 0.72 & 0.82 & 34 & 0.07 & $0.75-0.89^{b c}$ \\
\hline & Road-connected & 0.10 & 0.69 & 0.79 & 6 & 0.18 & $0.61-0.97^{b c}$ \\
\hline & Remote & 0.11 & 0.73 & 0.84 & 28 & 0.08 & $0.76-0.92^{b c}$ \\
\hline
\end{tabular}

† Vulnerability values may differ from those expected by adding Li and S values in graph due to rounding errors.

$\ddagger$ Values at $95 \%$ confidence level.

$\S \mathrm{V}$ value ranges with different superscripts $\left({ }^{a, b}\right)$ denote significant differences $(\alpha=.05)$ from each other. 
Appendix 3. Analysis results for unmerged GPS and Interview Datasets.

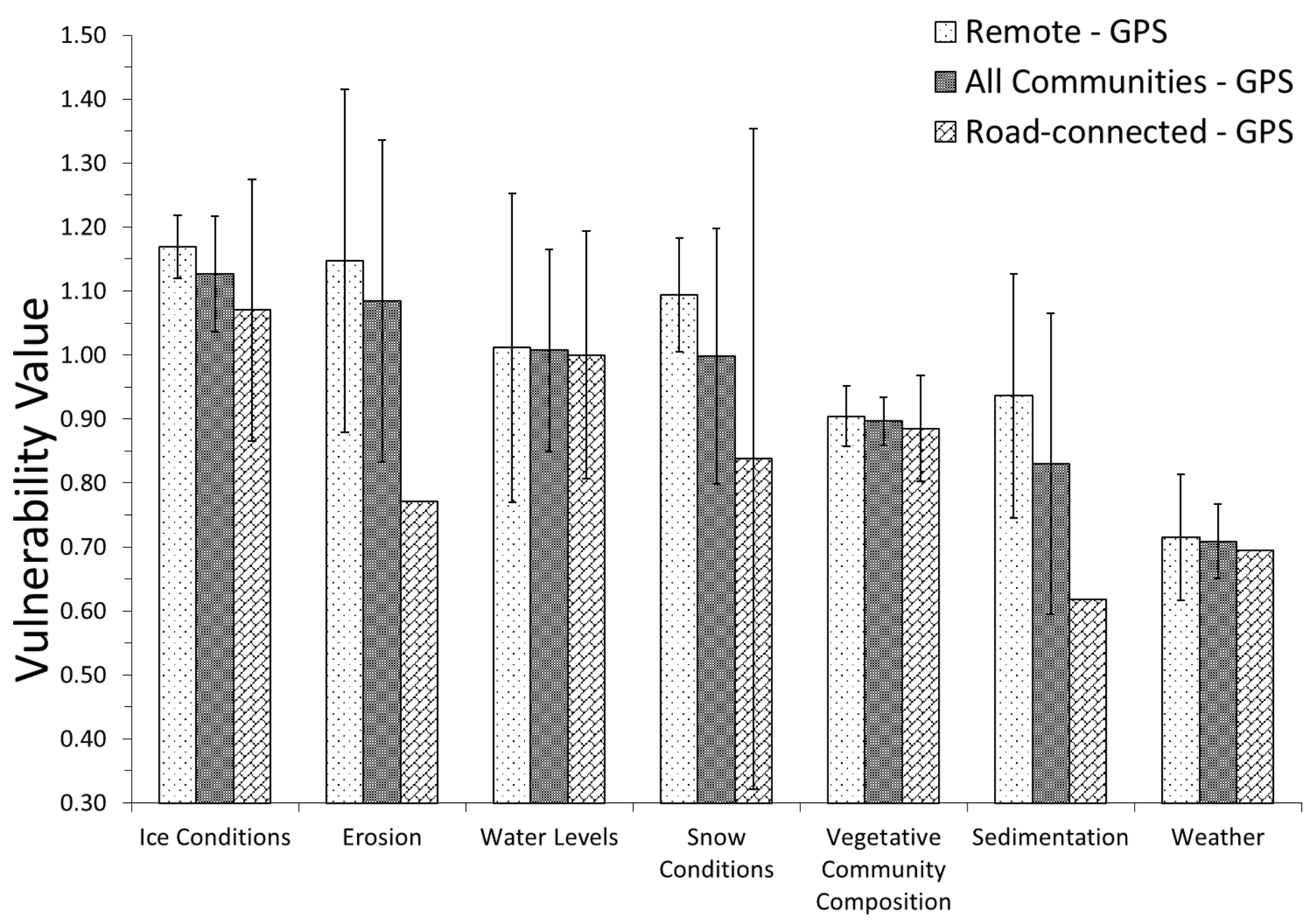

Figure A3.1. Graph comparing vulnerability values and associated margins of error for environmental conditions from GPS data among remote communities, road-connected communities and all communities combined. 
Table A3.1. Mean values for vulnerability analysis of GPS data among 9 communities, 3 road-connected communities and 6 remote communities.

\begin{tabular}{|c|c|c|c|c|c|c|c|}
\hline Condition & $\begin{array}{c}\text { Analysis } \\
\text { Level }\end{array}$ & $\begin{array}{c}\text { Average } \\
\text { Likelihood (Li) }\end{array}$ & $\begin{array}{c}\text { Average } \\
\text { Sensitivity (S) }\end{array}$ & $\begin{array}{c}\text { Vulnerability } \\
(\mathrm{V})^{+}\end{array}$ & $\begin{array}{c}\text { Number of } \\
\text { Observations }\end{array}$ & $\begin{array}{l}\text { Margin } \\
\text { of Error }^{\ddagger}\end{array}$ & $\begin{array}{l}\text { V Value } \\
\text { Range }^{\S}\end{array}$ \\
\hline \multirow[t]{3}{*}{ Ice Conditions } & All Communities & 0.34 & 0.79 & 1.13 & 124 & 0.09 & $1.04-1.12^{\mathrm{a}}$ \\
\hline & Road-connected & 0.31 & 0.76 & 1.07 & 39 & 0.20 & $0.87-1.27^{a b}$ \\
\hline & Remote & 0.36 & 0.81 & 1.17 & 85 & 0.05 & $1.12-1.22^{\mathrm{a}}$ \\
\hline \multirow[t]{3}{*}{ Erosion } & All Communities & 0.30 & 0.78 & 1.08 & 63 & 0.25 & $0.83-1.33^{\mathrm{ab}}$ \\
\hline & Road-connected & 0.07 & 0.70 & 0.77 & 5 & N/A & $\mathrm{N} / \mathrm{A}$ \\
\hline & Remote & 0.35 & 0.80 & 1.15 & 58 & 0.27 & $0.88-1.42^{\mathrm{ab}}$ \\
\hline \multirow[t]{3}{*}{ Water Levels } & All Communities & 0.28 & 0.72 & 1.01 & 98 & 0.16 & $0.85-1.17^{a b}$ \\
\hline & Road-connected & 0.28 & 0.72 & 1.00 & 36 & 0.19 & $0.89-1.19^{a b}$ \\
\hline & Remote & 0.28 & 0.73 & 1.01 & 62 & 0.24 & $0.77-1.25^{a b c}$ \\
\hline \multirow[t]{3}{*}{ Snow Conditions } & All Communities & 0.28 & 0.71 & 1.00 & 108 & 0.20 & $0.80-1.20^{\mathrm{abc}}$ \\
\hline & Road-connected & 0.29 & 0.55 & 0.84 & 40 & 0.52 & $0.32-1.36^{\mathrm{abc}}$ \\
\hline & Remote & 0.28 & 0.81 & 1.09 & 68 & 0.09 & $1.00-1.18^{\mathrm{a}}$ \\
\hline \multirow[t]{3}{*}{ Vegetative Community Composition } & All Communities & 0.15 & 0.74 & 0.90 & 53 & 0.04 & $0.86-0.94^{b}$ \\
\hline & Road-connected & 0.17 & 0.71 & 0.89 & 15 & 0.08 & $0.81-0.97^{b c}$ \\
\hline & Remote & 0.14 & 0.76 & 0.90 & 38 & 0.05 & $0.85-0.95^{b}$ \\
\hline \multirow[t]{3}{*}{ Sedimentation } & All Communities & 0.12 & 0.71 & 0.83 & 16 & 0.24 & $0.59-1.07^{a b c}$ \\
\hline & Road-connected & 0.12 & 0.50 & 0.62 & 2 & N/A & $\mathrm{N} / \mathrm{A}$ \\
\hline & Remote & 0.12 & 0.81 & 0.94 & 14 & 0.19 & $0.75-1.13^{a b c}$ \\
\hline \multirow[t]{3}{*}{ Weather } & All Communities & 0.06 & 0.65 & 0.71 & 17 & 0.06 & $0.65-0.77^{b c}$ \\
\hline & Road-connected & 0.03 & 0.67 & 0.70 & 2 & $\mathrm{~N} / \mathrm{A}$ & N/A \\
\hline & Remote & 0.07 & 0.64 & 0.72 & 15 & 0.10 & $0.62-0.82^{c}$ \\
\hline
\end{tabular}

† Vulnerability values may differ from those expected by adding Li and S values in graph due to rounding errors.

¥ Values at $95 \%$ confidence level.

$\S \vee$ value ranges with different superscripts $\left({ }^{a, b}\right)$ denote significant differences $(\alpha=.05)$ from each other. 


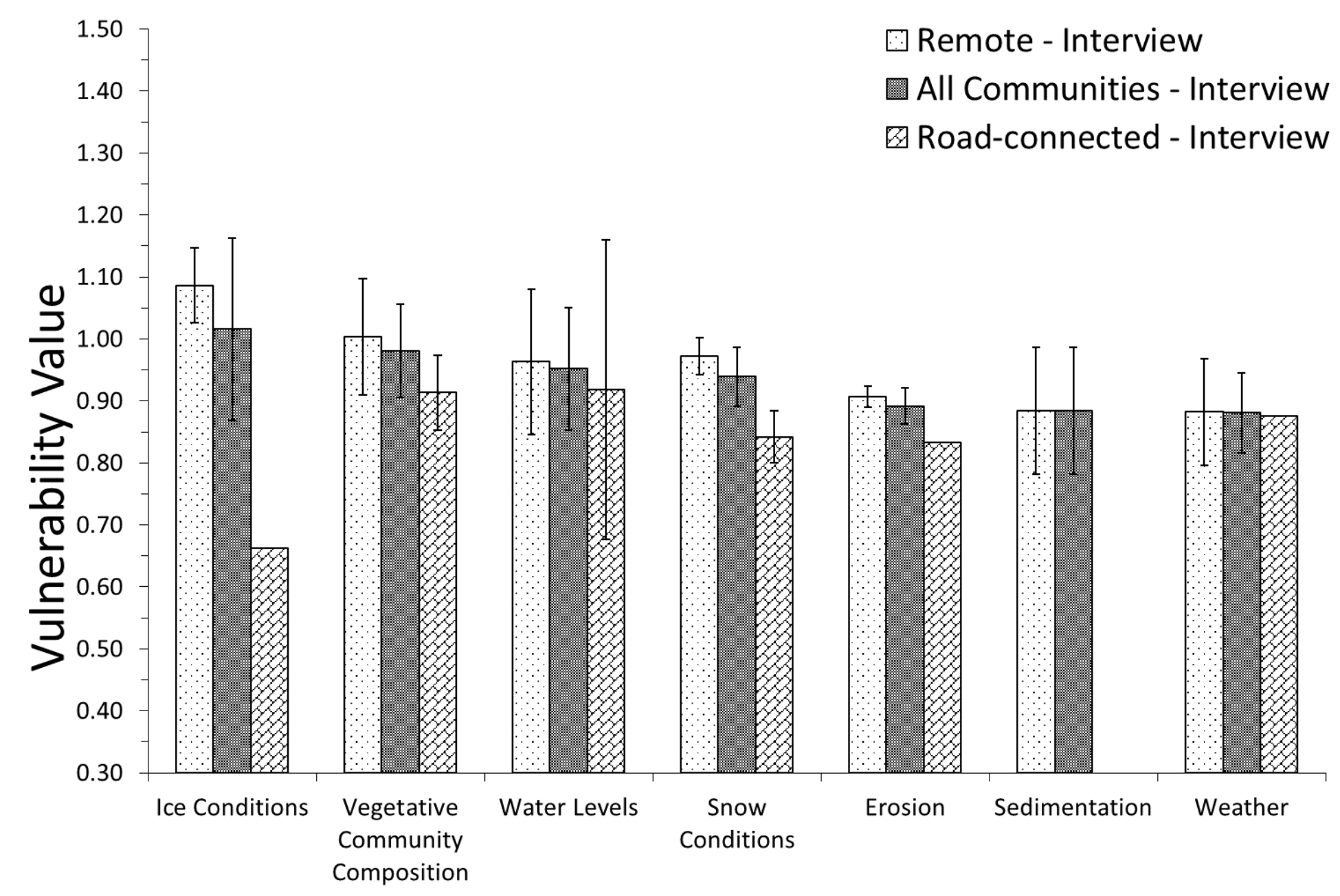

Figure A3.2. Graph comparing vulnerability values and associated margins of error for environmental conditions from interview data among remote communities, road-connected communities and all communities combined. 
Table A3.2. Mean values for vulnerability analysis of interview data among 8 communities, 2 road-connected communities and 6 remote communities.

\begin{tabular}{|c|c|c|c|c|c|c|c|}
\hline Condition & $\begin{array}{c}\text { Analysis } \\
\text { Level }\end{array}$ & $\begin{array}{c}\text { Average } \\
\text { Likelihood (Li) }\end{array}$ & $\begin{array}{c}\text { Average } \\
\text { Sensitivity (S) }\end{array}$ & $\begin{array}{c}\text { Vulnerability } \\
(\mathrm{V})^{+}\end{array}$ & $\begin{array}{c}\text { Number of } \\
\text { Observations }\end{array}$ & $\begin{array}{l}\text { Margin } \\
\text { of Error }^{\ddagger}\end{array}$ & $\begin{array}{l}\text { V Value } \\
\text { Range }^{\S} \\
\end{array}$ \\
\hline \multirow[t]{3}{*}{ Ice Conditions } & All Communities & 0.34 & 0.79 & 1.13 & 124 & 0.09 & $1.04-1.12^{\mathrm{a}}$ \\
\hline & Road-connected & 0.31 & 0.76 & 1.07 & 39 & 0.20 & $0.87-1.27^{\mathrm{ab}}$ \\
\hline & Remote & 0.36 & 0.81 & 1.17 & 85 & 0.05 & $1.12-1.22^{\mathrm{a}}$ \\
\hline \multirow[t]{3}{*}{ Erosion } & All Communities & 0.30 & 0.78 & 1.08 & 63 & 0.25 & $0.83-1.33^{\mathrm{ab}}$ \\
\hline & Road-connected & 0.07 & 0.70 & 0.77 & 5 & N/A & N/A \\
\hline & Remote & 0.35 & 0.80 & 1.15 & 58 & 0.27 & $0.88-1.42^{\mathrm{ab}}$ \\
\hline \multirow[t]{3}{*}{ Water Levels } & All Communities & 0.28 & 0.72 & 1.01 & 98 & 0.16 & $0.85-1.17^{a b}$ \\
\hline & Road-connected & 0.28 & 0.72 & 1.00 & 36 & 0.19 & $0.89-1.19^{\mathrm{ab}}$ \\
\hline & Remote & 0.28 & 0.73 & 1.01 & 62 & 0.24 & $0.77-1.25^{a b c}$ \\
\hline \multirow[t]{3}{*}{ Snow Conditions } & All Communities & 0.28 & 0.71 & 1.00 & 108 & 0.20 & $0.80-1.20^{\mathrm{abc}}$ \\
\hline & Road-connected & 0.29 & 0.55 & 0.84 & 40 & 0.52 & $0.32-1.36^{a b c}$ \\
\hline & Remote & 0.28 & 0.81 & 1.09 & 68 & 0.09 & $1.00-1.18^{a}$ \\
\hline \multirow[t]{3}{*}{ Vegetative Community Composition } & All Communities & 0.15 & 0.74 & 0.90 & 53 & 0.04 & $0.86-0.94^{b}$ \\
\hline & Road-connected & 0.17 & 0.71 & 0.89 & 15 & 0.08 & $0.81-0.97^{b c}$ \\
\hline & Remote & 0.14 & 0.76 & 0.90 & 38 & 0.05 & $0.85-0.95^{b}$ \\
\hline \multirow[t]{3}{*}{ Sedimentation } & All Communities & 0.12 & 0.71 & 0.83 & 16 & 0.24 & $0.59-1.07^{a b c}$ \\
\hline & Road-connected & 0.12 & 0.50 & 0.62 & 2 & N/A & N/A \\
\hline & Remote & 0.12 & 0.81 & 0.94 & 14 & 0.19 & $0.75-1.13^{a b c}$ \\
\hline \multirow[t]{3}{*}{ Weather } & All Communities & 0.06 & 0.65 & 0.71 & 17 & 0.06 & $0.65-0.77^{b c}$ \\
\hline & Road-connected & 0.03 & 0.67 & 0.70 & 2 & N/A & N/A \\
\hline & Remote & 0.07 & 0.64 & 0.72 & 15 & 0.10 & $0.62-0.82^{c}$ \\
\hline
\end{tabular}

† Vulnerability values may differ from those expected by adding Li and $\mathrm{S}$ values in graph due to rounding errors.

¥ Values at $95 \%$ confidence level.

$\S \bigvee$ value ranges with different superscripts $\left({ }^{(a, b}\right)$ denote significant differences $(\alpha=.05)$ from each other. 